\title{
Is There a Relationship Between Serum Heart- Type Fatty Acid Binding Protein Level and Clinical Severity in Patients with Subarachnoid Hemorrhage?
}

\section{Subaraknoid Kanamaln Hastalarn Klinik Şiddeti ile Kalp Tipi Yăg Asidi Bağlayıcı Proteinin Serum Düzeyi Arasında İlişki Var mıdır?}

Metehan YILMAN ${ }^{1}$, Cengiz COKLUK ${ }^{2}$, Ahmet BAYDIN ${ }^{1}$, Turker YARDAN ${ }^{1}$, Celal KATI ${ }^{1}$, Murat GUNAY ${ }^{3}$, Murat MERIC ${ }^{4}$

${ }^{1}$ Ondokuzmayis University, Faculty of Medicine, Department of Emergency, Samsun, Turkey

${ }^{2}$ Ondokuzmayis University, Faculty of Medicine, Department of Neurosurgery, Samsun, Turkey

${ }^{3}$ Ondokuzmayis University, Faculty of Medicine, Department of Biochemistry, Samsun, Turkey

${ }^{4}$ Ondokuzmayis University, Faculty of Medicine, Department of Cardiology, Samsun, Turkey

Correspondence address: Ahmet BAYDIN / E-mail: abaydin@omu.edu.tr

\begin{abstract}
AIM: The aim of this study was to determine the serum heart-type fatty acid binding protein (H-FABP) levels and cardiac effects in patients presenting with subarachnoid hemorrhage $(\mathrm{SAH})$ and to investigate whether any correlation exists between the cardiac effects and $\mathrm{H}$-FABP.

MATERIAL and METHODS: Forty-six patients diagnosed as acute SAH in the emergency department were included in this study. Twenty healthy adults were included in the study to serve as controls. Twelve-lead ECG was performed on all patients on admission. H-FABP levels of patients were determined in serum samples taken on admission.

RESULTS: Serum H-FABP levels of patients were found to be significantly higher than those of controls $(p<0.05)$. There was no significant correlation between serum H-FABP levels and ECG changes. There was a moderate positive correlation between H-FABP serum levels and the grade according to the Hunt and Hess classification $(r=0.43, p<0.05)$. There was a weak positive correlation between $\mathrm{H}-\mathrm{FABP}$ serum levels and the grade according to the Fisher radiological classification $(r=0.38, p<0.05)$.
\end{abstract}

CONCLUSION: Serum H-FABP levels are increased in patients with SAH. Grades according to the Hunt and Hess and Fisher grading scales were shown to increase in conjunction with an increase in H-FABP levels.

KEYWORDS: Subarachnoid hemorrhage, Electrocardiography, Clinical severity, H-FABP

Öz

AMAÇ: Bu çalışmanın amacı, subaraknoid kanama (SAK) ile başvuran hastalarda serum H-FABP seviyesini ve kardiyak etkileri belirlemek ve kardiyak etkileri ile H-FABP arasında ilişkili olup olmadığını araştırmaktır.

YÖNTEM ve GEREÇLER: Acil serviste SAK tanısı alan 46 hasta çalışmaya alındı. Ayrıca kontrol grubunu oluşturmak üzere 20 sağlıklı erişkin çalışmaya dahil edildi. Tüm hastalara başvuru anında 12 derivasyonlu EKG çekildi. Hastalardan başvuru anında alınan kan örneklerinden H-FABP düzeyleri belirlendi.

BULGULAR: Hastaların serum H-FABP düzeylerinin kontrol grubuna göre anlamlı derecede yüksek olduğu tespit edildi $(p<0.05)$. Serum $H$-FABP seviyesi ve EKG değişiklikleri arasında anlamlı bir ilişki yoktu. Serum H-FABP düzeyleri ile Hunt Hess sınıflamasına göre evre artışı arasında orta derecede pozitif korelasyon vardı $(r=0.43, p<0.05)$. Serum H-FABP düzeyleri ile Fisher radyolojik sınıflamasına göre evre artışı arasında zayıf bir pozitif korelasyon vardı $(r=0.38, p<0.05)$.

SONUÇ: SAK'lı hastalarda serum H-FABP düzeyleri artmaktadır. Serum H-FABP düzeylerindeki artış ile Hunt-Hess ve Fisher Ölçeği arasında korelasyon vardır.

ANAHTAR SÖZCÜKLER: Subaraknoid kanama, Elektrokardiyografi, Klinik şiddet, H-FABP

\section{INTRODUCTION}

Spontaneous subarachnoid hemorrhage (SAH) is a serious problem encountered in emergency and neurosurgery practice (3). It is difficult to define a precise value regarding the incidence of $\mathrm{SAH}$; the reported incidence has ranged from 8 to 25 per $100,000(1,8,12,20,23,28)$. The initial severity of bleeding, cerebral vasospasm, repetitive bleeding, success of the surgical intervention, and postoperative complications are common factors that are effective on the morbidity and mortality of the cases (13). Data from the studies conducted 
show that the mortality rate varies, reaching a value of $50 \%$ in the first month after hemorrhage (26). It is important to conduct a precise evaluation of the patient's clinical status in the management of treatment modalities and determination of the prognosis. Cerebrovascular spasm (CVS) has an important role in the mortality and morbidity of the cases, and should be considered among the factors that may affect the clinical status of SAH (2).

Heart-type fatty acid binding protein (H-FABP) is a small protein $(15 \mathrm{kDa})$ in the cytoplasm of heart muscle cells. $\mathrm{H}$-FABP has been shown also in the distal tubule of the kidney, skeletal muscle and brain cells, lactating mammary glands, and the placenta. H-FABP and brain-type fatty acid binding protein (B-FABP) are the new potential markers for detecting brain damage (22).

\section{MATERIAL and METHODS}

This prospective study was performed in Ondokuzmayıs University, School of Medicine, Emergency Department, from January 2011 to October 2011. Forty-six patients with spontaneous SAH were included in this study. In addition, 20 healthy adults were enrolled in the study to serve as a control group. A detailed physical examination was performed in all patients in the emergency room during the first application. Data from the patients included in the study were recorded during the first application. The imaging modalities [X-ray, computerized brain tomography (BT), electrocardiography (ECG), angiography], duration of hospitalization, and the last status of the patient (healing, exitus, vegetative state, and referral) were recorded. Verbal and written consent was obtained from patients and their relatives. Exclusion criteria were as follows: presentation more than 24 hours after hemorrhage, traumatic $\mathrm{SAH}$, pregnant women with $\mathrm{SAH}$, presence of kidney, liver or heart failure with $\mathrm{SAH}$, and age less than 18 years. Venous blood samples were taken from patients diagnosed as $\mathrm{SAH}$ at presentation, and emergency biochemical investigations and complete blood count were done. In addition, to determine serum H-FABP levels, a $5 \mathrm{~mL}$ venous blood sample was taken at the same time. Blood samples were taken from a tube without anticoagulant and were centrifuged at $1500 \mathrm{~g} \mathrm{rpm}$ for 15 minutes. The serum polypropylene tubes were stored at $-70^{\circ} \mathrm{C}$ until the final analysis. The same procedures were performed for venous blood samples taken from patients in the control group. Serum $\mathrm{H}$-FABP levels were measured with the test kit HyCult (HK401) by using the monoclonal antibodies and non-competitive sandwich-type enzyme-linked immunosorbent assay (ELISA) method from Biotechnology (Uden, Netherlands). Measurements were made using the Tecan Sunrise ELISA Reader device. Clinical classification of patients was made according to the Hunt and Hess scale for clinical classification of SAH. BT scan was used for evaluating patients according to the Fisher radiological scale (Table I, II).

Exitus and surviving patients were grouped according to prognosis. All data were recorded using the SPSS 15.0 (Statistical Package for the Social Sciences) computer program. Because the data do not fit a normal distribution, nonparametric tests were used. The Mann-Whitney $U$ test was used for two-group comparisons.

For comparison of more than two groups, the Kruskal-Wallis analysis of variance followed by Bonferroni-corrected MannWhitney $U$ test was used, and Spearman correlation analysis was performed $(r=0.38)(p<0.05)$.

Continuous variables of the data evaluated were expressed as mean \pm standard deviation. The data do not fit a normal distribution; thus, descriptive statistics are presented as the median (min-max).

\section{RESULTS}

Of the 46 patients, 21 were males (45.7\%) and 25 were females (53.3\%). The mean age of the patients was $53.8 \pm 16.2$ years. The largest group of patients was between the ages of 46-55 years ( $n=13,28.3 \%)$ (Table III).

Seventy-eight percent of patients had several ECG changes. Most patients (91.3\%) showed normal sinus rhythm, and atrial fibrillation was found in $8.7 \%$ of the patients. The mean ECG velocity was found as $84.1 \pm 21.4$, while the median (min-max)

Table I: Hunt and Hess Classification

\begin{tabular}{l|l} 
Grade 1 & Asymptomatic, mild headache, neck stiffness \\
Grade 2 & Severe headache, neck stiffness, no neurological signs other than cranial nerve palsy \\
Grade 3 & Drowsiness, confusion, and moderate neurological signs \\
Grade 4 & Stupor, moderate-severe hemiparesis \\
Grade 5 & Deep coma and decerebrate posture
\end{tabular}

Table II: Fisher's Classification System (the amount of blood in brain tomography)

\begin{tabular}{l|l} 
Grade 1 & No detectable subarachnoid blood \\
Grade 2 & $\leq 1 \mathrm{~mm}$ in thickness, diffuse \\
\hline Grade 3 & Localized, $>1 \mathrm{~mm}$ in thickness \\
\hline Grade 4 & Intracerebral or intraventricular blood \\
\hline
\end{tabular}


value was 80 (50-165). Patients with SAH had significantly higher $\mathrm{H}-\mathrm{FABP}$ levels in serum compared to the control group (Table IV, Figure 1).

The neurological status of patients was evaluated according to the Hunt and Hess scale at the time of the first application, and 19 of 46 patients (41.3\%) were determined as Grade 1, followed in decreasing order of frequency by Grade 5, Grade 3-4, and Grade 2 (Figure 2).
There was a moderate positive correlation between H-FABP serum levels and the grade according to the Hunt and Hess classification $(r=0.43, p<0.05)$ (Table V, Figure 3).

There was a weak positive correlation between H-FABP serum levels and the grade according to the Fisher radiological classification ( $r=0.38, p<0.05$ ) (Table VI, Figure 4).

We examined the relationship between serum $\mathrm{H}$-FABP levels and prognosis, and found that $\mathrm{H}-\mathrm{FABP}$ levels were significantly

Table III: The Distribution of Patients According to Age and Gender

\begin{tabular}{|l|c|r|r|r|r|r|}
\hline Age (years) & Male & $(\%)$ & Female & $(\%)$ & Total & $(\%)$ \\
\hline $\mathbf{1 8 - 2 5}$ & 0 & $(0)$ & 0 & $(0)$ & 0 & $(0)$ \\
\hline $\mathbf{2 6 - 3 5}$ & 5 & $(23.8)$ & 0 & $(0)$ & 5 & $(10.9)$ \\
\hline $\mathbf{3 6 - 4 5}$ & 7 & $(33.3)$ & 5 & $(20)$ & 12 & $(26.1)$ \\
\hline $\mathbf{4 6 - 5 5}$ & 6 & $(28.6)$ & 7 & $(28)$ & 13 & $(28.3)$ \\
\hline $\mathbf{5 6 - 6 5}$ & 2 & $(9.5)$ & 2 & $(8)$ & 4 & $(8.5)$ \\
\hline $\mathbf{6 6}$ and over & 1 & $(4.8)$ & 11 & $(44)$ & 12 & $(26.2)$ \\
& 21 & $(100)$ & 25 & $(100)$ & 46 & $(100)$ \\
\hline
\end{tabular}

Table IV: H-FABP Levels in Patients and the Control Group

\begin{tabular}{|c|c|c|c|c|c|}
\hline & \multicolumn{2}{|c|}{ Patients $(n=46)$} & \multicolumn{2}{|c|}{ Controls $(n=20)$} & \multirow[t]{2}{*}{$\mathbf{p}$} \\
\hline & Mean \pm SD & Median & Mean \pm SD & Median & \\
\hline & & $(\min -\max )$ & & $(\min -\max )$ & \\
\hline H-FABP (ng/dl) & $19.9 \pm 29.5$ & $\begin{array}{c}7.99 \\
(2.3-134.2)\end{array}$ & $5.9 \pm 10.1$ & $\begin{array}{c}3.4 \\
(2.3-48.5)\end{array}$ & $<0.05$ \\
\hline
\end{tabular}

Table V: The Relationship Between H-FABP and Hunt and Hess Grade

\begin{tabular}{|l|c|c|c|c|c|c|}
\hline & Grade 1 & Grade 2 & Grade 3 & Grade 4 & Grade 5 & p \\
\hline Mean \pm SD & $9.7 \pm 11.8$ & $12.9 \pm 0.4$ & $20.4 \pm 19.4$ & $7.8 \pm 4.2$ & $41.6 \pm 46.2$ & \\
\hline Median & 5.9 & 12.9 & 11.8 & 8.4 & 23.8 & $<0.05$ \\
\hline (min-max) & $2.3-46.5$ & $12.6-13.2$ & $4.2-50.8$ & $2.5-13.1$ & $3.9-134.2$ &
\end{tabular}

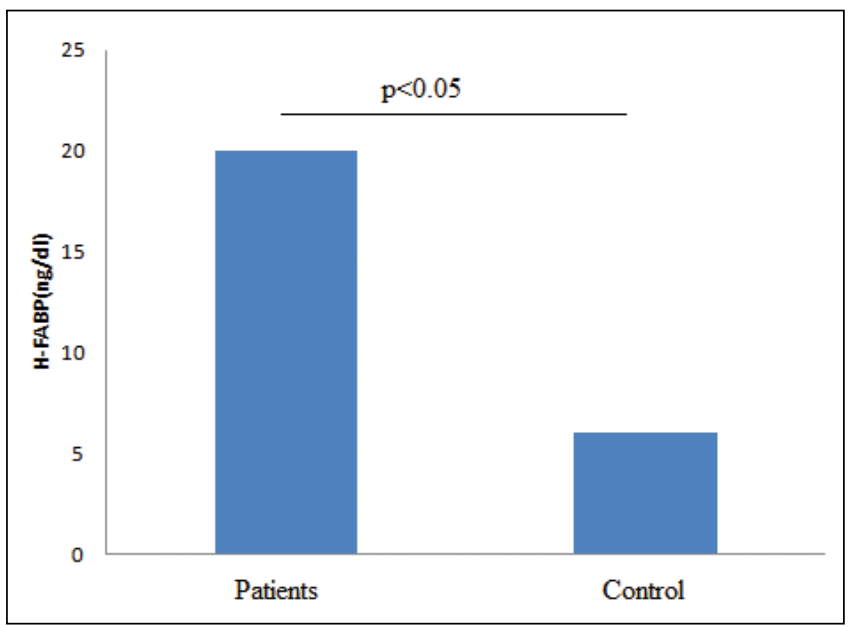

Figure 1: H-FABP levels in patients and the control group.

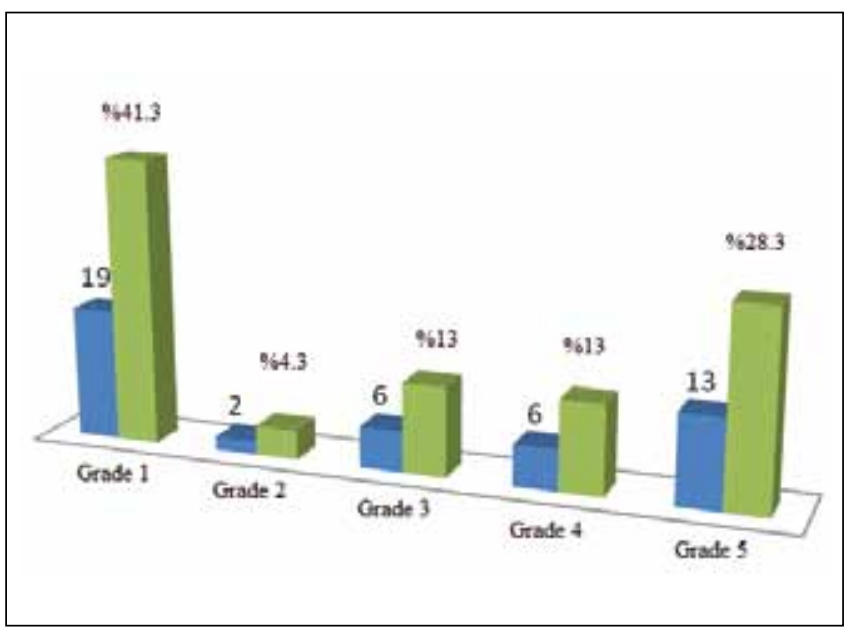

Figure 2: The distribution of patients according to the Hunt-Hess grading scale on admission. 
higher in exitus patients than survivors $(p<0.05)$ (Table VII, Figure 5).

The sensitivity and specificity of a serum $\mathrm{H}-\mathrm{FABP}$ level $\geq 6 \mathrm{ng} / \mathrm{dl}$ indicating mortality were $83.3 \%$ and $42.9 \%$, respectively. The positive predictive value was found as $48.4 \%$ and negative predictive value as $80 \%$.

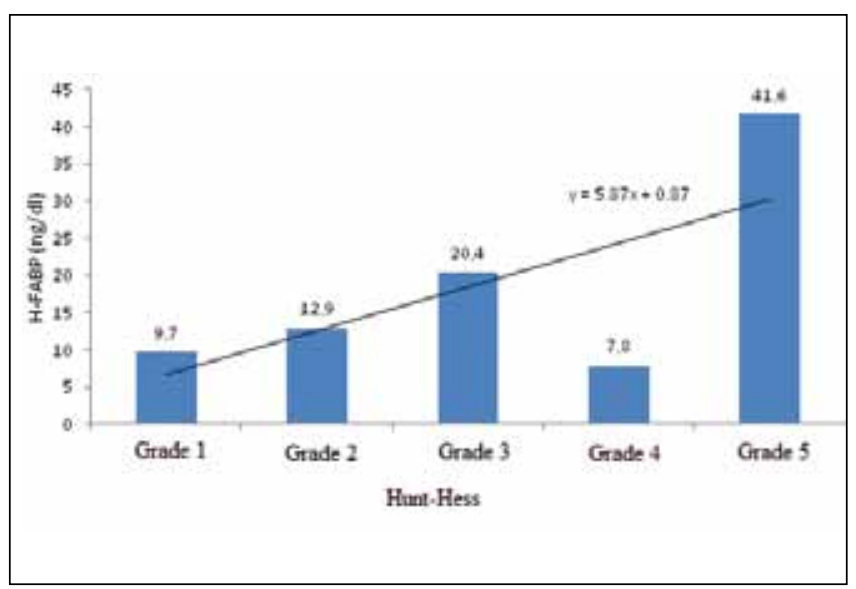

Figure 3: The relationship between $\mathrm{H}-\mathrm{FABP}$ and Hunt-Hess grade.

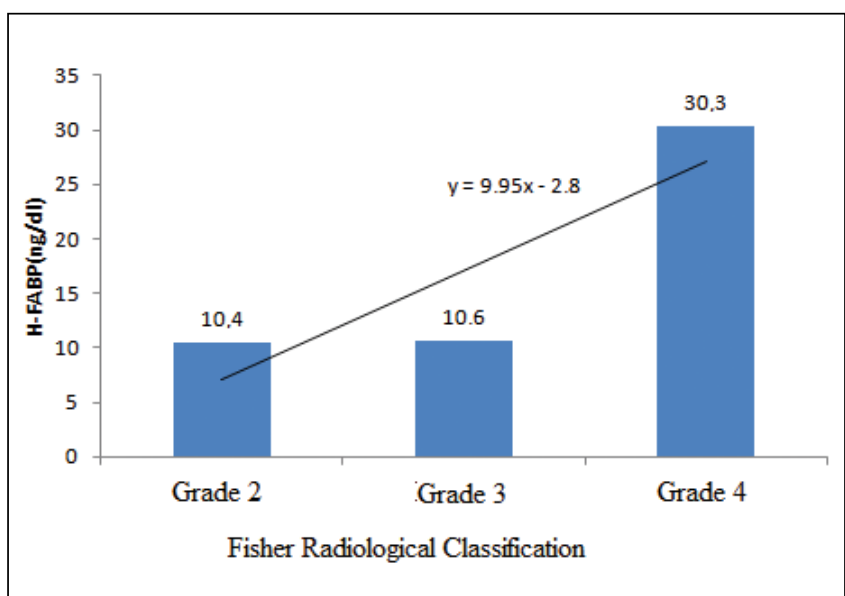

Figure 4: The relationship between H-FABP and Fisher grade.

\section{DISCUSSION}

Subarachnoid hemorrhage (SAH) accounts for 1-7\% of all strokes each year (6). It is known that in the United States, 30,000 people annually had $\mathrm{SAH}$ in the sixth decade due to cerebral aneurysm rupture (29). Hurtig et al. (11) and Kawasaki et al. (14) have reported a higher incidence of SAH in females than males. In addition, Kawasaki et al. (14) reported a mean age of $58.5 \pm 13.6$ years in patients with $\mathrm{SAH}$. In contrast to these studies, Kumral et al. (16) observed a higher percentage of $\mathrm{SAH}$ in male patients $(59.3 \%)$ than female patients, and they reported that the mean age of patients was $50.2 \pm 14$ years. In our study, we found that the rate of female patients with $\mathrm{SAH}$ was $53.3 \%$ and the mean age was $53.8 \pm 16.2$ years. These results were consistent with the literature in terms of gender and age.

Rudehill et al. (24) reported the presence of ECG changes in $82 \%$ of the patients with $\mathrm{SAH}$, while Sakr et al. (25) reported $66.7 \%$ of patients with SAH as having ECG changes without any cardiac abnormality. In the present study, we found ECG changes in $78 \%$ of the patients.

Heart-type fatty acid binding protein (H-FABP) is mainly released due to cardiac myositis. It is known that a small

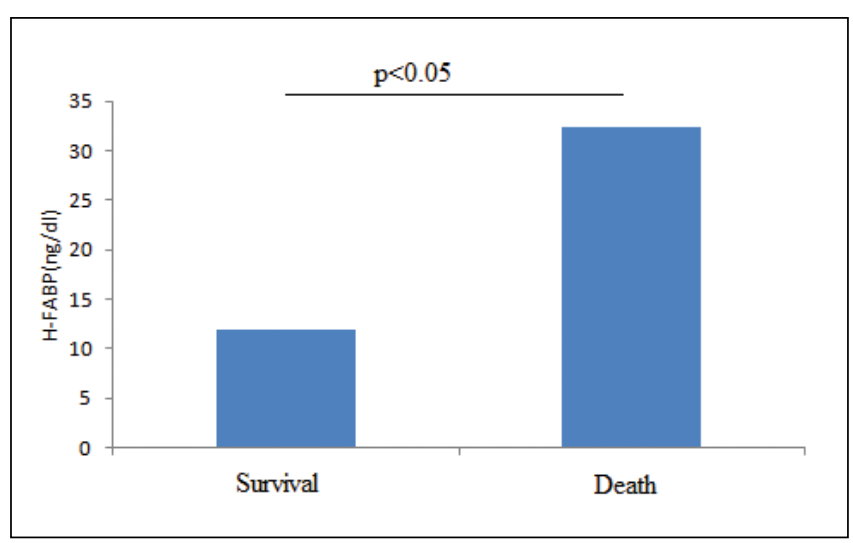

Figure 5: Comparison of the prognosis of patients according to H-FABP level.

Table VI: The Relationship Between H-FABP and Fisher Grades

\begin{tabular}{|c|c|c|c|c|c|}
\hline & Grade 1 & Grade 2 & Grade 3 & Grade 4 & $\mathbf{p}$ \\
\hline Mean \pm SD & 0 & $10.4 \pm 14.7$ & $10.6 \pm 9.4$ & $30.3 \pm 38.8$ & \\
\hline Median & 0 & 5.5 & 7.8 & 12.1 & $<0.05$ \\
\hline$(\min -\max )$ & 0 & $2.3-50.8$ & $2.8-37.5$ & $2.5-134.2$ & \\
\hline
\end{tabular}

Table VII: Comparison of the Prognosis of Patients According to H-FABP Level

\begin{tabular}{|c|c|c|c|c|c|}
\hline & \multicolumn{2}{|c|}{ Survivors $(n=28)$} & \multicolumn{2}{|c|}{ Exitus (n=18) } & \multirow[b]{2}{*}{$\mathbf{p}$} \\
\hline & Mean \pm SD & Median & Mean \pm SD & Median & \\
\hline & \multicolumn{2}{|r|}{ (min-max) } & \multicolumn{2}{|c|}{ (min-max) } & \\
\hline \multirow[t]{2}{*}{ H-FABP (ng/dl) } & $12 \pm 13.5$ & 6.6 & $32.3 \pm 41.7$ & 13.1 & $<0.05$ \\
\hline & & $(2.3-50.8)$ & & $2.4-134.2)$ & \\
\hline
\end{tabular}


amount is also released in skeletal muscle, distal tubular cells of the kidney, specific regions of the brain, lactating mammary glands, and the placenta. Recent developments suggest that FABPs can be used to evaluate brain damage. H-FABP is a potential new marker of brain damage (18). Wunderlich et al. (30) reported that H-FABP may be a rapid marker showing brain damage as well as clinical severity in ischemic stroke, and $\mathrm{H}$-FABP reached the highest value within the first 3 hours after the onset of stroke. In another study, it was reported that after mild traumatic brain injury and electroconvulsive therapy, the serum H-FABP levels were significantly elevated (21). Zanier et al. (32) documented that H-FABP levels were significantly increased in cerebrospinal fluid after SAH. Zimmerman-Ivol et al. (34) reported that serum H-FABP levels significantly increase in ischemic and hemorrhagic strokes. Wunderlich et al. (30) reported $\mathrm{H}-\mathrm{FABP}$ elevation in $45 \%$ of patients in their study. In our study, we found that mean serum H-FABP levels were $19.9 \pm 29.5 \mathrm{ng} / \mathrm{dL}$ in the patients with $\mathrm{SAH}$ versus $5.9 \pm 10.1 \mathrm{ng} / \mathrm{dL}$ in the control group. We can say that patients with SAH have significantly elevated serum H-FABP levels.

Although there are many classification systems for the evaluation of neurologic status in SAH patients, the Hunt and Hess classification is the most frequently used. We found that the mean grade according to the Hunt and Hess classification of our patients was 2.8. Zaroff et al. (33) reported a mean grade of 3.1 according to the Hunt and Hess classification, and the largest group (36.2\%) was Grade 3. Shinoda et al. (27) reported that their largest group (26.2\%) was Grade 2. Bozkus and Sarioglu (4) reported that Grade $1 \mathrm{SAH}$ was more likely seen under the age of 40 (66\%), and with an increase in age, this ratio fell to $30 \%$. In our study, the largest group was determined as Grade 1 (41.3\%). In the various studies, patients with Grades 1-3 (low grade) were defined as having a good prognosis, while those with Grades 4-5 (high grade) were defined as having a poor prognosis (17). Many neurosurgeons prefer not to operate on patients with poor prognosis because of the difficulty of the surgery, high mortality and morbidity, and low functional recovery (17). In different studies, patients with low grade have demonstrated better clinical results than those with high grade $(5,31)$. Koivisto et al. (15) reported that patients with Grades 4-5 have increased morbidity and mortality after surgical and endovascular treatment.

The Fisher grading scale is the most common method used to evaluate the $\mathrm{SAH}$ based on the computed tomography appearance (7). Although the Fisher scale was developed to estimate the CVS in patients with $\mathrm{SAH}$, it is reported to be correlated with clinical outcomes (19). Fisher et al. (7) also documented that an increase in the Fisher grade increases the rate of CVS. In one study, it was reported that the classification according to Hunt and Hess grade increases in direct proportion to increase in vasospasm (10). Goddard et al. (9) stated that the patient's neurological status at the time of arrival and the Fisher grade are effective on development of vasospasm. CVS has an important role in terms of mortality and morbidity, and is also considered to be among the factors that affect the clinical status of patients with SAH (2). To our knowledge, there is currently no study in the literature examining the relationship between H-FABP and the Hunt and Hess or Fisher classification system. In this study, we found that there was a moderate positive correlation between serum H-FABP levels and grade according to the Hunt and Hess classification. There was also a weak positive correlation between serum H-FABP levels and grade according to the Fisher radiological classification. According to these results, indicating that $\mathrm{H}$-FABP levels increase with increasing clinical severity, we think that H-FABP can be used as a new parameter for the evaluation of clinical severity and estimation of mortality in SAH.

\section{REFERENCES}

1. Bailey WL, Loeser JD: Intracranial aneurysms. JAMA 216: 1993-1996, 1971

2. Barker FG, Heros RC: Clinical aspects of vasospasm. Neurosurg Clin N Am 1:277-288, 1990

3. Biller J, Godersky JC, Adams H: Management of aneurysmal SAH. Stroke 19:1300-1305, 1988

4. Bozkus $H$, Sarioglu AC: Subarachnoid hemorrhage in the elderly. Turk J Geriatrics Geriatri 2:167-172, 1999

5. Deruty R, Pelissou-Guyotat I, Mottolese C, Amat D, Bognar $\mathrm{L}$ : Level of consciousness and age as prognostic factors in aneurysmal SAH. Acta Neurochir 132:1-8, 1995

6. Feigin VL, Lawes CM, Bennett DA, Anderson CS: Stroke epidemiology: A review of population-based studies of incidence, prevalence, and case fatality in the late 20th century. Lancet Neurol 2:43-53, 2003

7. Fisher CM, Kistler JP, Davis JM: Relation of cerebral vasospasm to subarachnoid hemorrhage visualized by computerized tomographic scanning. Neurosurgery 6:1-9, 1980

8. Garraway WM, Whisnant JP, Furlan AJ, Phillips LH, Kurland LT, O'Fallon WM: The declining incidence of stroke. N Engl J Med 300:449-452, 1979

9. Goddard AJ, Raju PP, Gholkar A: Does the method of treatment of acutely ruptured intracranial aneurysms influence the incidence and duration of cerebral vasospasm and clinical outcome? J Neurol Neurosurg Psychiatry 75:868-872, 2004

10. Greenberg MS: Handbook of Neurosurgery, third ed., Lakeland. Florida: Greenberg Graphics Inc, 1994:711-752

11. Hurtig HI, Reiwich M: Clinical aspect of cerebrovascular disease. In Golde Sohn ES, Apple SH (Eds), Neurology. Philadelphia: Lea \& Febiger, 1977:769-811

12. Kassell NF, Drake CG: Review of the management of saccular aneurysms. Neurol Clin 1:73-86, 1983

13. Kassell NF, Torner JC, Haley EC Jr, Jane JA, Adams HP, Kongable GL: The International Cooperative Study on the Timing of Aneurysm Surgery. Part 1: Overall management results. J Neurosurg 73:18-36, 1990

14. Kawasaki T, Azuma A, Sawada T, Sugihara H, Kuribayashi T, Satoh M, Shimizu Y, Nakagawa M: Electrocardiographic score as a predictor of mortality after subarachnoid hemorrhage. Circ J 66:567-570, 2002 
15. Koivisto T, Vanninen R, Hurskainen H, Saari T, Hernesniemi J, Vapalathi M: Outcomes of early endovascular versus surgical treatment of ruptured cerebral aneurysms. A prospective randomized study. Stroke 31:2369-2377, 2000

16. Kumral $E$, Isler $M$, Terzioglu $M$ : Hemorajik inmelerde elektrokardiografik bulgular: Subaraknoid kanamalarda . Türk Kardioloji Derneği Arş 18:35-38, 1990

17. Lee KC, Huh SK, Park HS, Shin YS, Lee KS: Management of poor grade patients with ruptured intracranial aneurysm. Keio J Med 46:69-73, 1997

18. Ockner RK, Manning JA, Poppenhausen RB, Ho WK: A binding protein for fatty acids in cytosol of intestinal mucosa, liver, myocardium, and other tissues. Science 177:56-58, 1972

19. Ogilvy CS, Carter BS: A proposed comprehensive grading system to predict outcome for surgical management of intracranial aneurysms. Neurosurgery 42:959-968, 1998

20. Pakarinen S: Incidence, etiology, and prognosis of primary subarachnoid hemorrhage. A study based on 589 cases diagnosed in a defined urban population during a defined period. Acta Neurol Scand 43:1-28, 1967

21. Pelsers MM, HanhoffT, Van der Voort $D$, Arts $B$, Peters $M$, Ponds R, Honig A, Rudzinski W, Spener F, de Kruijk JR, Twijnstra A, Hermens WT, Menheere PP, Glatz JF: Brain- and heart-type fatty acid-binding proteins in the brain: Tissue distribution and clinical utility. Clin Chem 50:1568-1575, 2004

22. Pelsers MM, Hermens WT, Glatz JF: Fatty acid-binding proteins as plasma markers of tissue injury. Clin Chim Acta 352:15-35, 2005

23. Rasmussen $P$, Busch $H$, Haase J, Hansen J, Harmsen A, Knudsen V, Marcussen E, Midholm S, Olsen RB, Rosenørn J, Schmidt K, Voldby B, Hansen L: Intracranial saccular aneurysms. Results of treatment in 851 patients. Acta Neurochir 53:1-17, 1980

24. Rudehill A, Olsson GL, Sundqvist K, Gordon E: ECG abnormalities in patients with subarachnoid haemorrhage and intracranial tumours. J Neurol Neurosurg Psychiatry 50:1375-1381, 1987
25. Sakr YL, Lim N, Amaral AC, Ghosn I, Carvalho FB, Renard M, Vincent JL: Relation of ECG changes to neurological outcome in patients with aneurysmal subarachnoid hemorrhage. Int J Cardiol 96:369-373, 2004

26. Saveland H, Sonesson B, Ljunggren B, Brandt L, Uski T, Zygmunt S, Hindfelt B: Outcome evaluation following subarachnoid hemorrhage. J Neurosurg 64:191-196, 1986

27. Shinoda J, Kimura T, Funakoshi T: Clinical features and outcome in 68 cases of aneurysmal subarachnoid hemorrhage without aneurysm repair. Neurol Med Chir (Tokyo) 29: 811-815, 1989

28. Van der Werf AJ: Clinical aspects of subarachnoid hemorrhage and significance of vasospasm. Psychiatr Neurol Neurochir 75:411-415, 1972

29. Wardlaw JM, White PM: The detection and management of unruptured intracranial aneurysms. Brain 123:205-221, 2000

30. Wunderlich MT, Hanhoff T, Goertler M, Spener F, Glatz JF, Wallesch CW, Pelsers MM: Release of brain-type and heart-type fatty acid-binding proteins in serum after acute ischaemic stroke. J Neurol 252:718-724, 2005

31. Yoshikai S, Nagata S, Ohara S, Yuhi F, Sakata S, Matsuno $\mathrm{H}$ : A retrospective analysis of the outcomes of patients with aneurysmal subarachnoid hemorrhages: A focus on the prognostic factors. Japanese. Neurol Surg (Tokyo) 24: 733-738, 1996

32. Zanier ER, Longhi L, Fiorini M: Increased levels of CSF heart-type fatty acid-binding protein and tau protein after aneurysmal subarachnoid hemorrhage. Acta Neurochir Suppl 102:339-343, 2008

33. Zaroff JG, Rordorf GA, Newell JB, Ogilvy CS, Levinson JR: Cardiac outcome in patients with subarachnoid hemorrhage and electrocardiographic abnormalities. Neurosurgery 44: 34-40, 1999

34. Zimmermann-Ivol CG, Burkhard PR, Le Floch-Rohr J, Allard L, Hochstrasser DF, Sanchez JC: Fatty acid binding protein as a serum marker for the early diagnosis of stroke: A pilot study. Mol Cell Proteomics 3:66-72, 2004 